УДК $340.12+343.01$

DOI https://doi.org/10.32837/apdp.v0i85.1862

М. М. Олексюк

\title{
СУЧАСНА АНГЛО-АМЕРИКАНСЬКА ФІЛОСОФІЯ КРИМІНАЛЬНОГО ПРАВА: КОНЦЕПЦІЇ ТА ПРИНЦИПИ
}

Постановка проблеми. Становлення національних і міжнародних правових систем не можливе без творчого використання досягнень сучасної філософсько-правової думки. Імплементація основних її доктрин у правову практику стає особливо актуальною нині, коли перед людством постають чимало питань, що стосуються вироблення специфічного ставлення до наявних у суспільстві міжособистісних і міждержавних відносин, які характеризуються посиленням тенденцій, пов'язаних із процесами, які розглядаються у кримінальній площині.

Трактування суті злочину як явища, особливостей відповідальності за протиправні вчинки, а також узалежненої від цього системи покарання як реагування на скоєні діяння стають важливими елементами філософсько-правового дискурсу у XXI столітті. Саме тому вивчення досвіду теоретичного осмислення кримінально-правових явищ дає можливість виробити загальні принципи становлення сучасного кримінального права. В силу цього аналіз основних характеристик, концепцій і принципів сучасної зарубіжної філософії кримінального права не може не бути доречним.

Стан опрацювання. Аналіз наявної наукової філософської та правової літератури, публікацій, дисертаційних досліджень свідчить про те, що важливим аспектам розвитку зарубіжних філософсько-правових доктрин кримінального права XXI століття вітчизняні вчені-філософи, соціологи, політологи та правознавці приділяють мало уваги.

Серед таких праць, в яких розглядаються питання, що стосуються проблематики сучасної зарубіжної філософії кримінального права, можна зазначити напрацювання Є.В. Атрошкевич, Є.Ю. Полянського, Д. Ягунова. Вони здебільшого стосуються хронологічних рамок, що віддалені від сьогодення, не торкаються процесів XXI століття, аналізують погляди лише певних визначених зарубіжних вчених, не містять узагальнюючого дослідження філософсько-правових доктрин сучасності.

Праці 0.0. Бандури та В.М. Братасюк дають можливість визначити основні постмодерні тенденції становлення філософії права на зламі століть, проте проблем філософії кримінального права не аналізують. Для формування загальної картини оцінки вкладу зарубіжної філософії права у справу розвитку правової теорії доречними будуть праці В.А. Бачиніна, В.С. Бігуна, В.К. Грищука, А.А. Козловського, С. Максимова, П.М. Рабіновича, С.С. Сливки.

Ця стаття продовжує мій попередній дискурс, що стосується розвитку зарубіжної філософсько-правової парадигми XXI століття, і містить аналіз доктринальних висновків таких провідних філософів права як Д. Гусак, Е. Дафф, А. Норрі, А. Ріпштейн, В. Тадрос.

(C) М. М. Олексюк, 2020 
Мета статті полягає в аналізі основних теоретичних висновків представників сучасної зарубіжної філософії кримінального права.

Виклад основного матеріалу. Серед теоретичних напрацювань представників сучасної зарубіжної філософсько-правової думки важливе місце займають питання покарання. Пріоритетним напрямом такого роду досліджень у ХХІ століття стала популяризація тих каральних теорій, які відображають особливості сучасного розвитку цивілізаційного простору. Нині ми стали свідками ренесансу ретрибутивістського підходу до покарання, коли відплата трактується найкращим його способом реакції на будь-яке порушення права.

Аналіз цієї теорії покарання зустрічаємо у працях британського філософа права А. Норрі. Ренесанс ретрибутивізму у кримінально-правовій та філософсько-правовій традиції він пов'язує із характерним для сучасної епохи зацікавленням питаннями прав людини як відповідальної, дієвої та раціональної особистості. Виходячи із тези про те, що «ретрибутивісти стверджують, що сучасні утилітарні та реформаторські теорії не здатні осягнути ті основні поняття прав та відповідальності особистості, які стосуються її свободи та незалежності», Норрі підкреслює актуальність ретрибутивістської теорії в сучасному кримінально-правовому та філосософсько-правовому дискурсі [3, с. 300].

Його позиція також грунтується на тезі про індивідуалістську суть ретрибутивізму. Він схильний вважати, що всезагальною проблемою сучасної ліберальної кримінально-правової та філософської традиції виступає твердження про особливе значення індивідуальної відповідальності як підстави правомірного покарання, яке фіксує взаємозв'язок моралі і права як форм соціального регулювання. «Центральна проблема ретрибутивістської теорії покарання полягає в тому, що вона спиралася на ідеальну концепцію особистості для того, щоб зробити дві речі: сформувати концепцію відповідального морального суб'єкта, покарання якого було виправдано його попередньою діяльністю, а також концепцію моральної спільноти із узгодженими нормами, які зробили б можливим осудження та покарання», твердить Норрі [4, с. 107].

Такий підхід призводить до актуалізації суб'єктивних чинників покарання, коли особливе значення відіграє питання індивідуальних особливостей особистості через встановлення її індивідуальної відповідальності за свої вчинки. Норрі вважає, що ознакою ретрибутивізму стає його ідеальна індивідуалістична основа, яка встановлює антиномію між «ідеальною» концепцією особистості та «актуальністю» індивідуального життя сучасного суспільства.

Тут можна помітити суперечності на фоні дилеми «ідеальне-реальне», що сприяє нівелюванню тих характеристик, які свідчать про актуальність і доречність ретрибутивістського погляду на покарання особи за скоєні злочини. «Суб’єктивність, що представлена у ліберальному кримінальному праві та ретрибутивістській філософії, - зазначає Норрі, - орієнтована на «ідеальну» концепцію особистості, виключаючи «реальний» соціальний і моральний контекст, в якому проходить індивідуальна діяльність особи» [4, с. 104].

Концептуальні висновки сучасних зарубіжних філософів права стосовно покарання у філософському та правовому його вимірах неодмінно актуалізують питан- 
ня відповідальності як того поняття, що дозволяє визначити шляхи протидії правопорушенням.

Специфічний концепт відповідальності представляє канадський філософ права А. Ріпштейн, відомий своїми працями на філософсько-правову тематику, один із провідних політичних філософів сучасності, продовжувач традицій Дж. Ролза. Ще наприкінці XX століття він стверджував, що питання відповідальності займає центральне місце в сучасній світовій моральній думці, пов'язуючи ці висновки із тезою про тісну єдність поняття відповідальності та заслуги як у правовому, так і в суто моральному вияві, оскільки самі по собі вони «є моральними поняттями, що не мають жодного сенсу обособлено від інших моральних понять» [5, с. 5].

Ріпштейн переносить положення своєї концепції відповідальності із площини морально-етичної та політичної у юридично-правову, піднімаючи питання про те, яке значення відіграє встановлення тих критеріїв, на основі яких будуть визначатися результати діяльності (чи бездіяльності) особи. I тут він звертає увагу на тісну єдність моралі, політики та права. «Оскільки передбачена законом концепція відповідальності може також розглядатися як вираження привабливих ідей свободи та рівності, це варто розглядати як спосіб тлумачення цих ідей, - зазначає Ріпштейн. - Таким чином, абстрактні міркування політичної філософії допомагають зрозуміти право, а право допомагає вияснити питання політичної філософії. Як закон, так і політична філософія прагнуть виправдати примус міркуваннями про справедливість» [6, с. 4].

Сучасна зарубіжна філософсько-правова парадигма звертає увагу на особливості становлення правових поглядів, теорій і концептів, які реалізуються у політико-правовій реальності. Розуміючисвоє завдання в межах цих важливих проблем, щовизначається необхідністю вироблення специфічної методології аналізу правового виміру становлення соціуму в сьогоднішніх складних і суперечливих умовах, провідні зарубіжні доктринологи виробляють свої позиції, які стають особливо актуальними.

Саме в такій площині здійснює осмислення кримінально-правових проблем один із провідних представників сучасної зарубіжної філософії права британський вчений Е. Дафф. Він звертає увагу на характеристику основних принципів аналізу кримінального права: «Правознавець, що прагне визначити принципи, якими структурована конкретна правова система, прагне визначити не тільки певну регулярність у поведінці суб'єктів цієї системи, але й нормативні принципи, якими вони керуються; забезпечити вимогу підтримки включення до неї особливого принципу, мусить довести, що той принцип дійсно керує діями професіоналів», зазначає він [1, с. 158].

Дафф вважає, що характеристика основних принципів філософського осмислення кримінального права неодмінно приводить до питання про місце у ньому численних суперечностей, які породжуються світоглядним і правовим дискурсом та стають важливим аспектом основних мотивів встановлення кримінальної відповідальності. Для вченого важливо підкреслити те, що такий хід думки єдиноможливий тільки при визнанні пріоритетності аналізу нормативної сторони кримінально-правового контенту. Він прагне довести, що наявність суперечностей у кримінальному праві може призвести до «загрозливого для здорового глузду кон- 
флікту» та вважає, що в такому випадку ці суперечності стають непримиренними та такими, що можуть сприяти формуванню правових колізій, які можуть значно ускладнити розуміння кримінально-правової реальності та призвести до неправильного трактування феномену кримінальної відповідальності.

У теоретичних напрацюваннях провідних представників сучасної зарубіжної філософії права не можна не помітити зацікавлення питаннями криміналізації як специфічного визнання діянь злочинними та встановлення відповідальності за їх вчинення. Серед активних промоутерів сучасної теорії криміналізації слід насамперед назвати американського професора Д. Гусака. Свій дискурс з приводу того, яким чином діяння визнаються злочинними, він розпочав ще в своїй монографічній праці «Надкриміналізація» (Overcriminalization). У цьому дослідженні він вказав на наявність надмірної криміналізації у сучасному світі, яка призводить до виявів несправедливості, в силу чого і поставив собі за мету визначити стримуючі фактори та допустиму межу повноважень держави встановлювати та здійснювати кримінальні покарання. У сфері політичного контенту Гусак наводив приклади додаткових перешкод, які можуть обмежувати права людини. Сукупність своїх теоретичних положень він назвав мінімалістичною теорією кримінальної відповідальності.

Гусак вважав, що для протидії надмірній криміналізації слід розробити низку стратегій, які він зводить до визначення обмежень, пов'язаних із каральною практикою у кримінальному праві. «Стверджую, що я здійснив лише найскромніший початок і встановив порядок денний для багатьох майбутніх досліджень», - зазначав він [2, с. 120]. Загальна теорія криміналізації, на думку Гусака, повинна виявити, захистити, удосконалити та спрямувати нормативні принципи, що обмежують каральні санкції.

В рамках свого наукового дискурсу Гусак звертає увагу на детермінантні тенденції формування засад криміналізації. Він схильний вважати, що до тих висновків, які складаються на основі такої форми соціальної регуляції як мораль, неодмінно слід залучати і політичний фактор. Можна констатувати те, що вчений прагне своєрідним чином сполучити внутрішньо-персональні аспекти криміналізації, що стосуються стану іï суб'єкта, із тими зовнішніми умовами, які існують на рівні її інституцій, провідне місце серед яких займає держава, функціонування якої зумовлено насамперед саме політичним фактором.

Методологічну основу вчення про криміналізацію, на думку Гусака, становить філософія, яка дозволяє поєднати морально-етичні та політичні аспекти цих процесів. «На мою думку, нам потрібна як політична, так і моральна філософія для формування відповідної теорії криміналізації, - зазначає він. - Моральної філософії однієї не вистачить. Правопорушники не заслуговують державного покарання, коли злочини, які вони вчиняють, не стосуються політичної спільноти, від імені якої діє держава» [2, с. 121].

У підходах Гусака до феномену криміналізації зустрічаємо спробу розібратися в питанні про роль у цьому держави. Він стверджує, що «кримінальне право не $є$ виправданим до тих пір, поки держава безпосередньо не виявляє істотного зацікавлення в утвердженні чесного інституту кримінального судочинства» [2, с. 123]. Актуалізація цього питання зводиться до його позиції стосовно кримінально-пра- 
вового патерналізму, адже саме тут простежується ставлення до питання про роль держави у становленні основних засад міжособистісних взаємовідносин, в тому числі і у кримінально-правовому вимірі.

Гусак заявляє, що напрацьовані ним висновки ставлять під сумнів основні постулати теорії кримінального патерналізму, хоча і зазначає, що йому бракує чіткого розуміння критеріїв вирішення, наскільки істотними можуть бути інтереси держави у кримінально-правових процесах.

«Я заперечував проти кримінального патерналізму на тій підставі, що держава навряд чи зможе досягти будь-якого істотного інтересу у запобіганні шкоди самому собі, караючи осіб, які порушують патерналістські закони. Я заперечував, що «покарання за порушення кримінального закону майже завжди є більш згубним для злочинця, ніж шкода, яку він заподіює чи ризикує сам, вступаючи в заборонену поведінку», - зазначає він, цитуючи свою роботу «Надкриміналізація» [2, с. 126].

Британський філософ права В. Тадрос формує концепцію ідеального та неідеального у теорії криміналізації. Причому можна побачити дихотономічний підхід до цих питань, оскільки ідеальне та неідеальне тлумачиться як вияв єдиного цілого, системи криміналізації, яка трактується як правовий і соціальний феномен. Вчений вважає, що «розмежування між ідеальним та неідеальним узгоджується із тим, чого вимагають норми кримінального права», визначаючи, що є два шляхи аналізу наслідків вчинення злочинів [8, с. 84]. Як бачимо, дискурс стосовно ідеального та неідеального у криміналізації зводиться до питання про причинно-наслідкові зв'язки у кримінально-правових відносинах, в яких аспектам виникнення фактору вчинення злочину відводиться пріоритетне місце.

Тадрос визначає два способи аналізу наслідків такої поведінки особи, які можуть бути запропоновані для розуміння системного характеру процесів криміналізації. До першого він відносить визначення тих наслідків, які наступають у випадку, якщо б кожний відповідав би тому, що від нього вимагають. В цьому випадку він трактує таку ситуацію як наявність ідеальних наслідків вчинення злочинів. «Ми також можемо розглянути те, що насправді станеться, знаючи, що деякі громадяни будуть це порушувати, а деякі державні чиновники будуть помилятися з повагою до покладених на них обов'язків», - стверджує Тадрос і вважає це констатацією неідеальних наслідків, які визначають природу криміналізації як правового феномену [8, с. 84].

Зарубіжна філософсько-правова думка виробила чимало концепцій, які повинні відповісти на питання, яким чином можна удосконалити політико-правове життя сучасного глобалізованого та неоднозначного світу. Одне з провідних місць у цьому належить А. Норрі. Важливе місце серед його досліджень займають питання становлення девіантної поведінки особи та особливостей віктимізації на національному та міжнародному рівнях.

Вчений вважає, що такого роду проблеми слід розглядати як такі, що стосуються вирішення соціологічних, соціально-історичних тапсихо-аналітичнихпитань. «Соціально-історичні, соціально-структурні та політичні рішення залишаються ключовими у вирішенні проблеми насильства на національному та міжнародному рівнях, але важко вважати, що ці рішення можуть діяти, якщоїх несприймаютьлюди, які взаємодіють зі своїми світами в ефективних моральних умовах», - зазначає Норрі [5, с. 393]. 
Норрі розробив специфічну концепцію прощення, яка базується на твердженні про значення любові як специфічного морального акту, що супроводжує становлення як моральної, так і правової парадигми в сучасних умовах процесу віктимізації. Вчений схильний підтримати ті положення філософії критичного реалізму, які розглядають феномен любові як поєднання низки його різновидів, послідовний процес становлення яких здійснюється в умовах розвитку соціуму.

У своїх висновках Норрі йде від феномену любові самого себе до любові іншого, до любовних стосунків між собою та іншими, згодом - до любові самого себе та інших в рамках ширшої спільноти, до любові інших в універсальному та специфічному вияві [5, с. 394-395]. Поєднання цих виявів любові, на думку вченого, і становить основу реалізації концепції прощення у складних стосунках осіб в умовах віктимізації та дозволяє виробити засади політики вирішення конфліктів в умовах сучасного вкрай нестабільного світу. «Це стосунки жертви та злочинця, їх спільнот як наслідок горя, яке ці стосунки приносять, - заявляє А. Норрі. - Вони засновуються на втратах, руїнах і трагедіях» [5, с. 399].

Можна стверджувати, що філософсько-правові погляди А. Норрі на феномен прощення у кримінальному праві виводяться із твердження про те, що в цьому випадку ми неодмінно маємо справу із загрозами та втратами, що супроводжують взаємовідносини злочинця та жертви, в силу чого слід з особливою увагою ставитися до процедурних питань.

Дискурс стосовно феномену прощення як на морально-етичному, так і на інституційному рівні у правових рамках неодмінно приводить дослідника до визнання таких взаємовідносин злочинця та жертви, за яких остання потрапляє в певне узалежнене становище, результатом якого є послаблення ії позиції щодо злочинця. «Прощення можна вважати подарунком, чимось, що дається, тим, що злочинець отримує від потерпілого. Здебільшого про це думають як про шлях в одному напрямі, і це в певному сенсі зрозуміло. Незважаючи на значний потенціал спільності, вихідна точка є асиметричною. Правопорушник не може за звичних обставин розраховувати на прощення від своєї жертви», - зазначає Норрі [5, с. 400-401]. Такі погляди британського філософа права виводяться із тези про пріоритетність моральних принципів, які визначають спрямованість кримінально-правових установок і формують засади ретрибутивістської концепції покарання.

\section{Висновки.}

1. Ріст зацікавленості формуванням ретрибутивістських концепцій покарання в умовах постійних виявів нестабільності в сучасному світі актуалізує суб'єктивні чинники покарання, значення яких аргументується тезою про визначальну роль індивідуальних особливостей особистості через встановлення її індивідуальної відповідальності за свої вчинки.

2. Перенесення положень англо-американської філософії кримінального права з площини морально-етичної у юридично-правову дає можливість вироблення критеріїв визначення результатів діяльності (чи бездіяльності) особи, що може бути використано для визначення міри відповідальності людини за свої вчинки в умовах її девіантної поведінки. 
3. Для філософського осмислення кримінально-правових проблем важливо підкреслити те, що наявність суперечностей у кримінальному праві фіксує як єдиноможливий шлях до визначення пріоритетності аналізу нормативної сторони кримінально-правового контенту. Ці суперечності стають непримиренними та такими, що можуть сприяти формуванню правових колізій, значно ускладнити розуміння кримінально-правової реальності та призвести до неправильного трактування феномену кримінальної відповідальності.

4. Англо-американська філософсько-правова традиція (Д. Гусак) поєднує внутрішньо-персональні аспекти криміналізації із тими зовнішніми умовами, що існують на рівні її інституцій, провідне місце серед яких займає держава, функціонування якої зумовлено політичними факторами.

5. Дихотомічний підхід до проблем криміналізації виявляється в концепції ідеального та неідеального у теорії криміналізації, які трактуються як вияв криміналізації як єдиного цілого правового та соціального феномену (В. Тадрос). Це актуалізує значення причинно-наслідкових зв'язків у кримінально-правових відносинах, коли проблемі виникнення фактору вчинення злочину відводиться пріоритетне місце.

6. Концепція прощення А. Норрі, яка базується на твердженні про значення любові в сучасних процесах віктимізації, формує засади політики вирішення конфліктів в рамках кримінально-правової практики, коли сторони правових відносин мають справу із загрозами та втратами.

\section{Jimepamypa}

1. Duff R.A. Principle and Contradiction in the Criminal Law: Motives and Criminal Liability. / Philosophy and the Criminal Law: Principle and Critique (Cambridge Studies in Philosophhy and Law). Cambridge : Cambridge University Press, 1998. P. 156 - 204.

2. Husak D. Convergent Ends, Divergent Means: A Response to My Critics. Criminal Justice Ethics. Vol. 28, № 1, May 2009. P. 119-134.

3. Norrie A. Thomas Hobbes and the Philosophy of Punishment. Law and Philosophy, Vol. 3, № 2 (1984). P. 299-320.

4. Norrie A. "Simulacra of Morality?" Beyond the Ideal / Actual Antinomies of Criminal Justice. Philosophy and the Criminal Law: Principle and Critique (Cambridge Studies in Philosophy and Law). Edited by Antony Duff. Cambridge : Cambridge University Press. 2009.

5. Norrie A. Love actually: law and the moral psychology of forgiveness. Journal of Critical Realism, 2018. № 17:4. P. 390-407.

6. Ripstein A. Equality, Luck, and Responsibility. Philosophy and Public Affairs. 1994. Vol. 23. № 1. P. 3-23.

7. Ripstein A. Equality, Responsibility, and the Law (Cambridge Studies in Philosophy and Law). Cambridge : Cambridge University. 1998.

8. Tadros V. The Architecture of Criminalization. Criminal Justice Ethics. Vol. 28, № 1, May 2009, P. 74-88. 


\begin{abstract}
Анотація
Олексюк М. М. Сучасна англо-американська філософія кримінального права: концепції та принципи. - Стаття.

Стаття присвячена аналізу основних концепцій і принципів англо-американської філософії кримінального права XXI століття. Розкривається суть ретрибутивістського погляду на покарання британського вченого А. Норрі, зокрема ствердження індивідуалістської суті ретрибутивізму, індивідуальної відповідальності як підстави правомірного покарання, ролі суб'єктивних чинників покарання.

Досліджується філософсько-правова парадигма А. Ріпштейна, який стверджує про тісну єдність відповідальності та заслуги як у правовому, так і в моральному вияві, що дозволяє виявити суть концептуальних висновків про покарання у філософському та правовому його вимірі та визначити шляхи протидії правопорушенням в сучасних умовах.

У статті аналізуються погляди британського вченого Е. Даффа, який вважає, що дослідження основних принципів філософського розуміння кримінально-правових проблем неодмінно призводить до питання про місце у цьому численних суперечностей, що породжуються світоглядним і правовим дискурсом, стають важливим аспектом основних мотивів встановлення кримінальної відповідальності.

У теоретичних напрацюваннях провідних представників сучасної зарубіжної філософії права не можна не помітити зацікавлення питаннями криміналізації як специфічного визнання діянь злочинними та встановлення відповідальності за їх вчинення. У статті підкреслюється значення наукового дискурсу стосовно проблем криміналізації американським вченим Д. Гусаком, який звертає увагу на детермінантні тенденції формування засад криміналізації. Констатується те, що вчений прагне своєрідним чином сполучити внутрішньо-персональні аспекти криміналізації, які стосуються стану ї̈ суб'єкта, із тими зовнішніми умовами, що існують на рівні її інституцій, провідне місце серед яких займає держава.

У статті аналізується концепція прощення британського філософа права А. Норрі, яка базується на твердженні про значення любові як специфічного морального акту, що супроводжує становлення як моральної, так і правової парадигми в сучасних умовах процесу віктимізації.

Ключові слова: кримінальне право, мораль, ретрибутивізм, відповідальність, принцип, суперечність, криміналізація, кримінальний патерналізм, прощення, віктимізація.
\end{abstract}

\title{
Summary
}

Oleksiuk M. M. Modern Anglo-American philosophy of law: conceptions and principles. - Article.

The article deals with the analysis of main conceptions and principles of Anglo-American philosophy of criminal law in 21st century. It explains the essence of retributivist view on punishment of British scholar A. Norrie, especially the statement on the individualist nature of retributivism. Also it concerns the explanations of individual liability as requirement for legal punishment and the role of subjective factors of punishment.

The article contains the research of legal philosophical paradigm of A. Ripstein, who stresses on the divertive coherence of liability and merit in legal and moral dimensions. Hence, it gives an opportunity to emphasize the conceptual conclusions on issue of punishment in philosophical and legal fields and outline the ways of delinquency's prevention in modern times.

The article analyses views of British scholar A. Duff, who believes that research of the main principles of philosophical understanding of criminal legal problems arises the question on its various contradictions, which are resulted by ideological and legal discourse, and becomes the important aspect of the main reasons of the criminal liability establishment. It has to be noted that there is a strong academic interest about the issues of criminalization as a specific constitution of act as illegal in theoretical works of foreign representatives of modern philosophy of law.

The article emphasizes the importance of scholar discourse on issues of criminalization initiated by the American scholar D. Husak, who points on the determinative trends of setting the grounds of criminalization. It is shown that mentioned scholar tries in a specific manner to connect the intrapersonal aspects of criminalization, which relate to its subject, with the external factors, which exist on the level of its institutions, where the state is one of them.

The article analyses the concept of forgiveness provided by the British philosopher of law A. Norie, which bases on the statement about the role of love as a specific moral action, which follows the establishment of either moral and legal paradigm in victimization in modern times.

Key words: criminal law, moral, retributivism, liability, principle, contradiction, criminalization, criminal paternalism, forgiveness, victimization. 